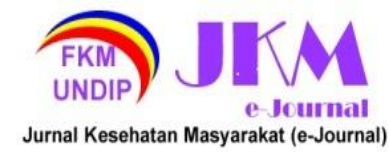

JURNAL KESEHATAN MASYARAKAT (e-Journal)

Volume 9, Nomor 5, September 2021

ISSN: 2715-5617 / e-ISSN: 2356-3346

http://ejournal3.undip.ac.id/index.php/jkm

\title{
HUBUNGAN PENERAPAN POLA DIET DAN AKTIFITAS FISIK DENGAN STATUS KADAR GULA DARAH PADA PENDERITA DM TIPE 2 DI RSUD PETALA BUMI PEKANBARU TAHUN 2020
}

\author{
Jasmiyul Sri Santi ${ }^{1}$, Winda Septiani ${ }^{*}$ \\ 1Program Studi Kesehatan Masyarakat, STIKes Hang Tuah Pekanbaru \\ ${ }^{*}$ Corresponding Author: magisterwinda@gmail.com
}

\begin{abstract}
ABSTRAK
Kadar gula darah adalah jumlah atau konsentrasi glukosa yang terdapat dalam darah. Tingginya kadar gula darah dapat mengakibatkan berbagai komplikasi. Rumah Sakit Petala Bumi merupakan salah satu rumah sakit di Kota Pekanbaru. Berdasarkan data dari RS Petala bumi didapatkan bahwa jumlah pasien DM tipe 2 mengalami peningkatan, yaitu pada tahun 2017 sebanyak 75 pasien, tahun 2018 sebanyak 92 pasien dan tahun 2019 sebanyak 141 pasien. Tujuan penelitian ini yaitu untuk mengetahui hubungan penerapan pola diet dan aktifitas fisik terhadap status kadar gula darah pada penderita DM Tipe 2 di RSUD Petala Bumi Pekanbaru tahun 2020. Jenis penelitian ini adalah analitik kuantitatif dengan desain cross sectional. Populasi adalah pasien penderita DM tipe 2 di RSUD Petala Bumi pada tahun 2019 yaitu sebanyak 141 orang dengan jumlah sampel sebanyak 82. Penelitian ini dilakukan di RSUD Petala Bumi Pekanbaru pada bulan April-Juli tahun 2020. Pengambilan sampel dilakukan dengan metode consecutive sampling dengan pengumpulan data menggunakan kuesioner, wawancara dan penelusuran dokumen. Analisis data menggunakan chi-square. Hasil penelitian ini yaitu ada hubungan antara jumlah makanan ( $p$ value $=0,004$ ), jenis makanan ( $p$ value $=0,001$ ), jadwal makanan ( $p$ value $=0,013$ ), aktivitas fisik ( $p$ value $=0,001$ ) dengan kadar gula darah di RSUD Petala Bumi Pekanbaru. Saran yaitu diharapkan bagi penderita DM agar menjadikan penelitian ini sebagai bahan referensi dalam meningkatkan penerapan pola diet berupa 3J (jumlah, jenis, dan jadwal) dan aktivitas fisik agar status kadar gula darah dapat terkontrol pada pasien DM tipe 2 melalui kegiatan yang berada di klinik gizi dan perawatan rumah sakit.
\end{abstract}

\section{Kata Kunci : Status Kadar Gula Darah, Pola Diet 3J, Aktivitas Fisik}

\section{PENDAHULUAN}

Kadar gula darah adalah jumlah atau konsentrasi glukosa yang terdapat dalam darah. Menurut kamus kedokteran gula darah adalah produk akhir dan merupakan sumber energi utama organisme hidup yang kegunaannya dikontrol oleh insulin. ${ }^{1}$ Kadar gula darah yang tinggi berhubungan dengan penyakit Diabetes Mellitus (DM).

DM atau yang lebih dikenal dengan penyakit kencing manis merupakan penyakit kelainan metabolik yang dikarakteristikkan dengan tingginya kadar gula darah serta kelainan metabolisme karbohidrat, lemak, dan protein yang diakibatkan oleh kelainan sekresi insulin, kerja insulin, maupun keduanya. Kadar gula darah yang tetap tinggi pada penderita DM menimbulkan penyakit penyulit pada berbagai organ tubuh seperti pembuluh darah otak dapat menyebabkan stroke, pembuluh darah mata menimbulkan kebutaan, pembuluh darah jantung menimbulkan penyakit jantung koroner dan pembuluh darah ginjal menimbulkan gagal ginjal kronik.

Pada penelitian PERKENI (2011) dengan responden di masyarakat umum, didapatkan sebanyak 8,29\% memiliki kadar gula darah sewaktu melebihi $200 \mathrm{mg} / \mathrm{dL}$ dan 15,63\% dengan kadar gula darah 140-199 mg/dL. Jika seseorang memiliki kadar gula darah sewaktu melebihi 200 berarti dia sudah dapat dikatakan menderita diabetes. Kadar gula darah normal sebelum makan yaitu $70-130 \mathrm{mg} / \mathrm{dL}$, dua jam setelah makan yaitu kurang dari $140 \mathrm{mg} / \mathrm{dL}$ dan kadar gula darah puasa 8 jam yaitu kurang dari $100 \mathrm{mg} / \mathrm{dL}^{2}$

Dalam melaksanakan diet untuk mengatur kadar gula darah, penderita DM tipe 2 harus mengikuti anjuran dalam aturan $3 \mathrm{~J}$, yaitu jumlah makanan, jenis makanan dan jadwal makan. ${ }^{2}$ Jenis dan jumlah makanan yang banyak mengandung gula serta jadwal makan yang tidak teratur dapat meningkatkan kadar gula darah sehingga terjadilah DM tipe 2. Tanpa pengaturan jumlah, jenis, dan jadwal makanan sepanjang hari, akan sulit mengontrol kadar gula darah dalam batas normal. ${ }^{3}$ Jika aturan diet tersebut tidak diikuti maka kadar gula darah akan tidak stabil. Padahal tujuan dari penatalaksanaan DM tipe 2 dalam jangka pendek adalah mencapai target pengendalian glukosa darah. ${ }^{2}$

Pada penelitian ini dilihat hubungan penerapan diet $3 \mathrm{~J}$ dengan status kadar gula darah. Berbagai penelitian menunjukkan adanya 


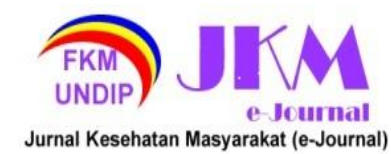

hubungan antara penerapan $3 \mathrm{~J}$ terhadap status kadar gula darah. Hasil penelitian Verawati, dkk (2014) di Purworejo menunjukkan adanya hubungan antara penerapan jumlah makanan dengan kadar gula darah $(p=0,001){ }^{4}$ Pada penelitian Toharin (2015) di Batang, menunjukkan bahwa ada hubungan antara aturan jenis makanan dengan status kadar gula darah $(p=0,001){ }^{4}$ Selain itu, penelitian Kurniawati (2007) juga menunjukkan adanya hubungan antara aturan jadwal makan dengan kadar gula darah $(p=0,003) .^{5}$

Langkah perubahan gaya hidup lainnya yang tidak terpisahkan dengan diet adalah aktivitas fisik. Pada penderita DM tipe 2, aktivitas fisik juga berperan utama dalam pengaturan kadar gula darah. Pada saat melakukan aktivitas fisik, resistensi insulin akan berkurang, sebaliknya sensitivitas insulin meningkat, hal ini menyebabkan kebutuhan insulin pada DM tipe 2 akan berkurang. ${ }^{6}$ Berdasarkan studi metaanalisis Norris, et al (2014) terdapat 22 studi penelitian (randomized controlled trial) dalam melihat intervensi aktivitas fisik pada 4659 responden menunjukkan adanya pengaruh terhadap kadar gula darah dan penurunan berat badan. ${ }^{7}$ Pada penelitian eksperimental Indriyani (2007) di Purbalingga menunjukkan adanya pengaruh aktivitas fisik terhadap penurunan kadar gula darah $(p=0,0001) .{ }^{8}$ Hasil penelitian cross-sectional Teh, et.al (2015) di Malaysia dengan sampel penderita DM yang merupakan masyarakat urban dan rural menunjukkan adanya hubungan signifikan antara aktivitas fisik dengan pengontrolan glukosa darah $(p<0,05) .^{9}$

Rumah Sakit Petala Bumi merupakan salah satu rumah sakit di Kota Pekanbaru. Berdasarkan data dari RS Petala bumi didapatkan bahwa paa tahun 2017 terdapat 3.715 pasien DM, pada tahun 2018 terdapat 3.657 pasien DM dan pada tahun 2019 terdapat 2.803 pasien DM. Walaupun jumlah ini mengalami penurunan, namun jumlah pasien DM tipe 2 mengalami peningkatan, yaitu pada tahun 2017 sebanyak 75 pasien, tahun 2018 sebanyak 92 pasien dan tahun 2019 sebanyak 141 pasien.

Pada survei pendahuluan yang telah dilakukan peneliti pada bulan Februari tahun 2020 di Rumah Sakit Petala Bumi dengan metode observasi dan wawancara terkait pelaksanaan dan pemberian anjuran diet dan aktivitas fisik pada 10 orang pasien yang berumur $>40$ tahun, didapatkan hasil bahwa penderita DM tipe 2 yang telah diberikan anjuran diet oleh petugas kesehatan menyampaikan bahwa mereka menganggap anjuran diet tersebut penting akan tetapi sulit menerapkan sehari-hari karena harus sesuai dengan aturan 3J sehingga status kadar gula darah mereka buruk. Dalam hal aktivitas fisik, penderita DM tipe 2 lebih banyak melakukan aktivitas rumah tangga.

Penerapan diet dan aktivitas fisik yang belum sesuai akan menghasilkan tidak terkendalinya kadar gula darah dalam batas normal, timbulnya komplikasi dan berbagai penyakit menahun dari penderita DM tipe 2. Dari hasil studi pendahuluan dan hasil fakta lapangan peneliti yang telah didapat mengenai penerapan diet dan kadar gula darah, membuat peneliti perlu melakukan penelitian mengenai hubungan penerapan pola diet berdasarkan $3 \mathrm{~J}$ (Jumlah, Jenis, dan Jadwal) dan aktivitas fisik terhadap status kadar gula darah pada penderita DM tipe 2 di Rumah Sakit Petala Bumi tahun 2020.

\section{METODE PENELITIAN}

Jenis penelitian ini adalah penelitian kuantitatif dengan desain penelitian cross sectional. Lokasi penelitian ini dilakukan di RSUD Petala Bumi Kota Pekanbaru, sedangkan waktu penelitian dilaksanakan pada bulan Juni hingga Agustus tahun 2020 dengan populasi seluruh pasien penderita DM tipe 2 di RSUD Petala Bumi pada tahun 2019-2020 yaitu sebanyak 141 orang. Total sampel keseluruhan yaitu 82 sampel yang diambil dari pasien rawat jalan dan rawat inap DM tipe 2 di RSUD Petala Bumi. Pengambilan sampel dilakukan dengan metode consecutive sampling. Data dianalisis secara univariat dan bivariat menggunakan uji chi square.

\section{HASIL DAN PEMBAHASAN Analisa Univariat}

Analisis ini untuk memperoleh distribusi frekuensi masing-masing variabel independen dan variabel dependen. Data disajikan dalam bentuk tabel distribusi frekuensi sebagai berikut: 


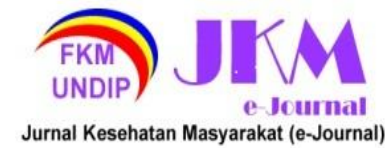

JURNAL KESEHATAN MASYARAKAT (e-Journal)

Volume 9, Nomor 5, September 2021

ISSN: 2715-5617 / e-ISSN: 2356-3346

http://ejournal3.undip.ac.id/index.php/jkm

Tabel 1. Distribusi Frekuensi Responden Berdasarkan Variabel di RSUD Petala Bumi Pekanbaru Tahun 2020

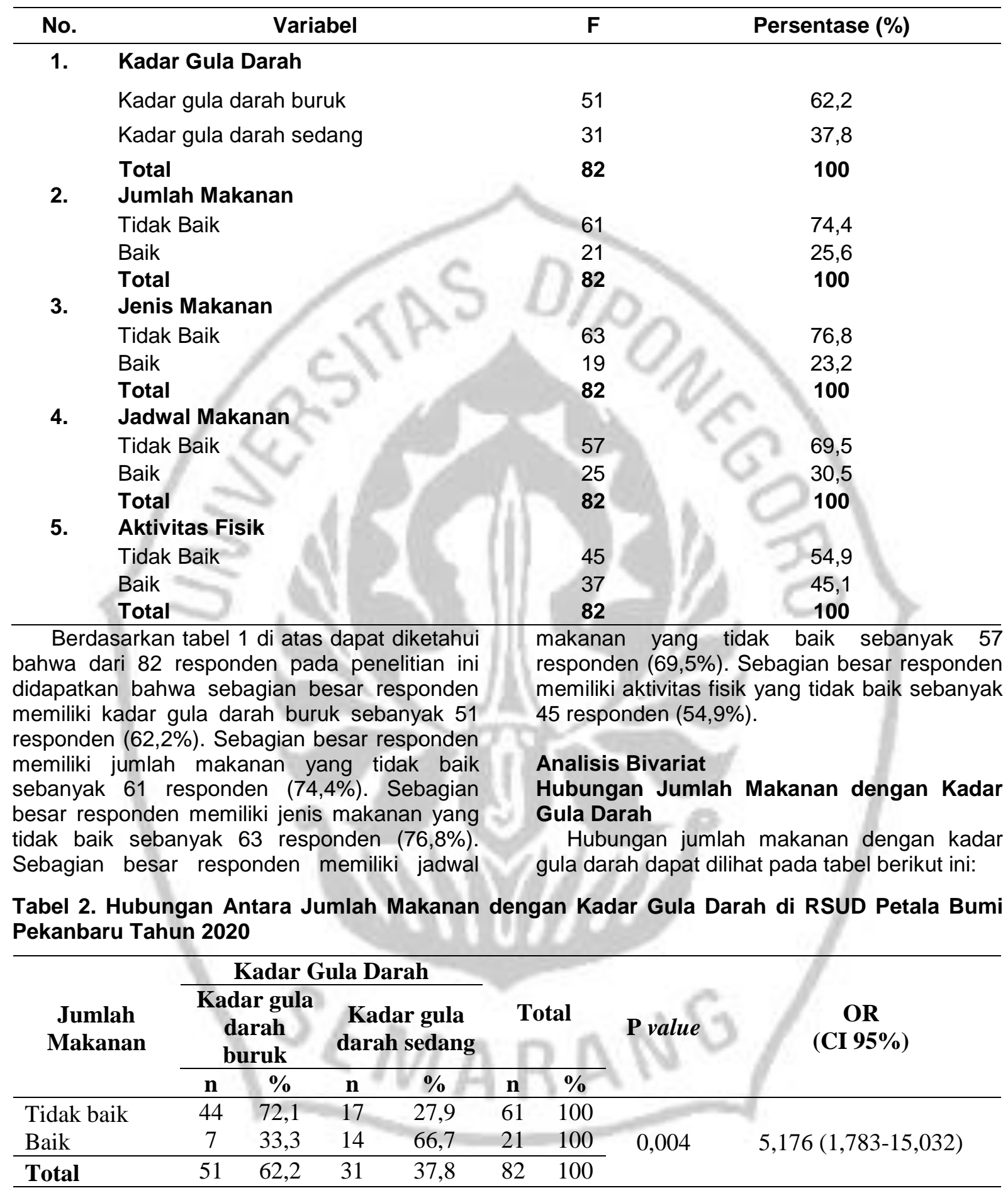

Berdasarkan tabel 3 diatas dari 61 responden dengan jumlah makanan yang tidak baik, yang memiliki kadar gula darah buruk sebanyak 44 responden (72,1\%). Dari 21 responden dengan jumlah makanan yang baik, yang memiliki kadar gula darah buruk sebanyak
7 responden (33,3\%). Hasil uji statistik chi square, diperoleh $p$ value $=0,004$ artinya $p$ value kecil dari 0,05 maka ada hubungan yang signifikan antara jumlah makanan dengan kadar gula darah di RSUD Petala Bumi Pekanbaru. 


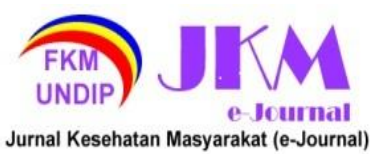

Nilai Odds Ratio $(\mathrm{OR})=5,176$ dengan nilai Confidence Interval 95\% $(\mathrm{Cl})=1,783-15,032$ artinya responden dengan jumlah makanan yang tidak baik 5,1 kali berpeluang memiliki kadar gula darah buruk daripada responden dengan jumlah makanan yang baik.

Berdasarkan hasil penelitian ada hubungan yang signifikan antara jumlah makanan dengan kadar gula darah di RSUD Petala Bumi Pekanbaru.

Berdasarkan hasil penelitian oleh Toharin (2015) menunjukkan adanya hubungan antara anjuran jumlah makanan dengan status kadar gula darah $(p=0,018) .{ }^{10}$ Hal tersebut menunjukkan jika penderita mengikuti anjuran jumlah makanan maka status kadar gula darahnya akan terkontrol. Selain itu, pada penelitian Muliani (2013) menunjukkan adanya hubungan antara asupan energi, karbohidrat, protein dan serat dengan status kadar gula darah, tetapi juga menunjukkan tidak adanya hubungan antara asupan lemak dengan status kadar gula darah. ${ }^{11}$ Penelitian oleh Setyoadi (2018) menunjukkan hasil penurunan kadar glukosa darah dan 5 responden yang mengalami peningkatan kadar glukosa darah setelah diberikan intervensi. ${ }^{12}$

Terdapat beberapa cara untuk menentukan jumlah kalori yang dibutuhkan pasien DM saat memulai perencanaan makan, di antaranya adalah dengan memperhitungkan kebutuhan kalori basal yang besarnya $25-30$ kalori/kgBB ideal, lalu ditambah atau dikurangi bergantung pada beberapa faktor seperti jenis kelamin umur, aktivitas, dan status gizi. Selain itu, komposisi energi terdiri dari karbohidrat $45-65 \%$ dari energi total, protein $10-20 \%$ dari energi total, dan lemak $20-25 \%$ dari energi total. ${ }^{2}$

Aturan diet untuk DM adalah memperhatikan jumlah makan yang dikonsumsi. Jumlah makan (kalori) yang dianjurkan bagi penderita DM adalah makan lebih sering dengan porsi kecil, sedangkan yang tidak dianjurkan adalah makan dalam porsi banyak/besar sekaligus. Tujuan cara makan seperti ini adalah agar jumlah kalori terus merata sepanjang hari, sehingga beban kerja organ-organ tubuh tidak berat, terutama organ pankreas. Penderita DM, diusahakan mengkonsumsi asupan energi yaitu kalori basal 25 - $30 \mathrm{kkal} / \mathrm{kg}$ BB normal yang ditambah kebutuhan untuk aktivitas dan keadaan khusus, protein $10-20 \%$ dari kebutuhan energi total, lemak $20-25 \%$ dari kebutuhan energi total dan karbohidrat sisa dari kebutuhan energi total yaitu $45-65 \%$ dan serat $25 \mathrm{~g} /$ hari.
Sejumlah faktor mempengaruhi respon glikemik yang terkandung dalam makanan antara lain sifat pati (amilosa, amilopektin, pati), jumlah serat makanan dan jenis gula. Salah satu jenis gula yang tidak boleh digunakan lebih dari $5 \%$ total asupan energi adalah sukrosa (gula murni). ${ }^{2}$ Pemanis alternatif dapat digunakan sebagai pengganti gula, asal tidak melebihi batas aman konsumsi harian (Accepted Daily Intake). Dalam penggunaannya, pemanis berkalori seperti fruktosa dan gula alkohol perlu diperhitungkan kandungan kalorinya sebagai bagian dari kebutuhan kalori sehari karena dapat memberikan efek samping pada lemak darah. ${ }^{2}$

Analisis peneliti bahwa jumlah makanan dapat mempengaruhi kadar gula darah pasien. Semakin banyak jumlah makanan yang diserap tanpa memperhatikan zat gizi dan kebutuhan tubuh, maka akan semakin tinggi kadar gula darah pasien. Konsumsi minuman manis seperti minuman ringan susu, teh, kopi, minuman berpemanis, jus buah erat pengaruhnya dengan peningkatan gula darah DM tipe 2. Hal itu sejalan dengan hasil penelitian ini bahwa responden masih mengkonsumsi minuman ringan dan manis. Selain itu, responden juga mengkonsumsi bahan santan, kelapa, minyak kelapa yang merupakan lemak jenuh dalam jumlah yang melebihi batas $<7 \%$. Jumlah asupan lemak jenuh perlu dibatasi karena selain berkaitan dengan kadar gula darah, kaitan lainnya adalah dari tujuan utama diet DM yaitu mencegah timbulnya penyakit komplikasi diabetes seperti kardiovaskular.

Masih banyaknya responden yang tidak baik dalam menerapkan jumlah makanan dipengaruhi oleh adanya peningkatan rasa lapar atau yang disebut polyphagia. Polyphagia ini menyebabkan penderita DM tipe 2 akan selalu merasa lapar karena kalori yang dihasilkan dari makanan akan dimetabolisasikan menjadi glukosa dalam darah dan tidak seluruhnya dapat dimanfaatkan dalam tubuh. Disamping itu, responden yang baik dalam menerapkan jumlah makanan, banyak yang memiliki status kadar gula darah sedang dan sebagian diantaranya memiliki kadar gula darah yang baik.

\section{Hubungan Jenis Makanan dengan Kadar Gula Darah}

Hubungan jenis makanan dengan kadar gula darah dapat dilihat pada tabel berikut ini: 


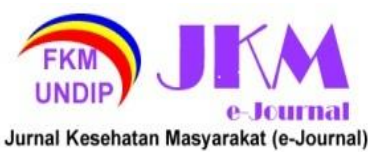

JURNAL KESEHATAN MASYARAKAT (e-Journal)

Volume 9, Nomor 5, September 2021

ISSN: 2715-5617 / e-ISSN: 2356-3346

http://ejournal3.undip.ac.id/index.php/jkm

Tabel 3. Hubungan Antara Jenis Makanan dengan Kadar Gula Darah di RSUD Petala Bumi Pekanbaru Tahun 2020

\begin{tabular}{|c|c|c|c|c|c|c|c|c|}
\hline \multirow{3}{*}{ Jenis Makanan } & \multicolumn{4}{|c|}{ Kadar Gula Darah } & \multirow{2}{*}{\multicolumn{2}{|c|}{ Total }} & \multirow{3}{*}{ P value } & \multirow{3}{*}{$\begin{array}{c}\text { OR } \\
\text { (CI 95\%) }\end{array}$} \\
\hline & \multicolumn{2}{|c|}{$\begin{array}{l}\text { Kadar gula } \\
\text { darah buruk }\end{array}$} & \multicolumn{2}{|c|}{$\begin{array}{l}\text { Kadar gula } \\
\text { darah sedang }\end{array}$} & & & & \\
\hline & $\mathbf{n}$ & $\%$ & $\mathbf{n}$ & $\%$ & $\mathbf{n}$ & $\%$ & & \\
\hline Tidak baik & 46 & 73 & 17 & 27 & 63 & 100 & \multirow{3}{*}{0,001} & \multirow{3}{*}{$7,576(2,468-24,237)$} \\
\hline Baik & 5 & 26,3 & 14 & 73,7 & 19 & 100 & & \\
\hline Total & 51 & 62,2 & 31 & 37,8 & 82 & 100 & & \\
\hline
\end{tabular}

Berdasarkan tabel 3 diatas dari 63 responden dengan jenis makanan yang tidak baik, yang memiliki kadar gula darah buruk sebanyak 46 responden (73\%). Dari 19 responden dengan jenis makanan yang baik, yang memiliki kadar gula darah buruk sebanyak 5 responden (26,3\%). Hasil uji statistik chi square, diperoleh $p$ value $=0,001$ artinya $p$ value kecil dari 0,05 maka ada hubungan yang signifikan antara jenis makanan dengan kadar gula darah di RSUD Petala Bumi Pekanbaru.

Nilai Odds Ratio $(\mathrm{OR})=7,576$ dengan nilai Confidence Interval 95\% $(\mathrm{Cl})=2,468-24,237$ artinya responden dengan jenis makanan yang tidak baik 7,5 kali berpeluang memiliki kadar gula darah buruk daripada responden dengan jenis makanan yang baik.

Berdasarkan hasil penelitian ada hubungan yang signifikan antara jenis makanan dengan kadar gula darah di RSUD Petala Bumi Pekanbaru. Nilai Odds Ratio $(\mathrm{OR})=7,576$ dengan nilai Confidence Interval $95 \%(\mathrm{Cl})=$ 2,468-24,237 artinya responden dengan jenis makanan yang tidak baik 7,5 kali berpeluang memiliki kadar gula darah buruk daripada responden dengan jenis makanan yang baik.

Jenis makanan pada food recall bahwa sebagian besar pasien memakan makanan sumber karbohidrat, protein hewani, buahbuahan, makanan selingan, minuman serta penggunaan gula pasir, gula merah, minyak dan santan dari frekuensi yang lebih dari yang dianjurkan. Pasien DM tidak dianjurkan mengkonsumsi gula yang berlebihan dan dianjurkan menggunakan gula khusus DM ke dalam makanan dan minuman sebagai pengganti gula. Jumlah kalori yang dikonsumsi secara berlebihan akan meningkatkan kadar gula darah pasien. Dengan pemberian edukasi melalui konseling gizi dapat memperbaiki pola makan pasien. Kepatuhan merupakan tingkat pasien dalam melaksanakan cara pengobatan dan perilaku yang disarankan oleh dokter atau paramedis, sebagaimana ketentuan yang disarankan pada penderita diabetes mellitus. Banyak penderita diabetes mellitus yang mengalami kegagalan dalam pengobatan, hal ini dapat disebabkan oleh berbagai faktor diantaranya tidak menjalani diet dengan baik. Ketidakpatuhan pada klien diabetes adalah masalah kesehatan serius yang menjadi tantangan besar pada keberhasilan pelayanan kesehatan.

Menurut penelitian yang dilakukan Toharin (2015), menunjukkan bahwa ada hubungan antara aturan jenis makanan dengan status kadar gula darah $(p=0,001) \cdot{ }^{10}$ Selain itu, hasil penelitian Verawati, dkk (2014) juga menunjukkan adanya hubungan antara jenis makanan dengan kadar gula darah $(p=0,001){ }^{4}$ Menurut Verawati, dkk (2014) adanya hubungan tersebut bisa terjadi karena sebagian besar responden sudah mengetahui tentang anjuran diet DM, akan tetapi rata- rata responden tidak mengetahui tentang jenis makanan yang mengandung karbohidrat kompleks dan sederhana, tidak patuh pada prinsip diet, jadwal makan yang tidak tepat, dan konsumsi jenis makanan pantangan. ${ }^{4}$

Menurut Almatsier (2016), jenis makanan yang diperbolehkan dalam penatalaksanaan diet DM tipe 2 terdiri dari sumber karbohidrat kompleks tetapi dibatasi seperti nasi, roti, mi, kentang, singkong, ubi, dan sagu; sumber protein rendah lemak seperti ikan, ayam tanpa kulit, susu skim, tempe, tahu, dan kacangkacangan; sumber lemak dalam jumlah terbatas yaitu bentuk makanan yang mudah dicerna, terutama diolah dengan cara dipanggang, dikukus, direbus, dan dibakar. ${ }^{13}$

Penyebab lain masih banyaknya responden yang tidak baik dalam menerapkan jenis makanan yang akhirnya status kadar gula darah buruk adalah karena responden tidak mengolah makanan dengan benar seperti menggoreng dengan minyak goreng yang dipakai sampai beberapa kali. Penderita DM tipe 2 mempunyai risiko tinggi untuk mendapatkan penyakit jantung dan pembuluh darah, sehingga lemak dan kolesterol dalam makanan perlu dibatasi.

\section{Hubungan Jadwal Makanan dengan Kadar Gula Darah}

Hubungan jadwal makanan dengan kadar gula darah dapat dilihat pada tabel berikut ini: 


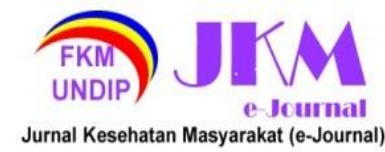

JURNAL KESEHATAN MASYARAKAT (e-Journal)

Volume 9, Nomor 5, September 2021

ISSN: 2715-5617 / e-ISSN: 2356-3346

http://ejournal3.undip.ac.id/index.php/jkm

Tabel 4. Hubungan Antara Jadwal Makanan dengan Kadar Gula Darah di RSUD Petala Bumi Pekanbaru Tahun 2020

\begin{tabular}{|c|c|c|c|c|c|c|c|c|}
\hline \multirow{3}{*}{$\begin{array}{l}\text { Jadwal } \\
\text { Makanan }\end{array}$} & \multicolumn{4}{|c|}{ Kadar Gula Darah } & & & \multirow{3}{*}{ P value } & \multirow{3}{*}{$\begin{array}{c}\text { OR } \\
(\text { CI 95\%) }\end{array}$} \\
\hline & \multicolumn{2}{|c|}{$\begin{array}{c}\text { Kadar gula } \\
\text { darah } \\
\text { buruk }\end{array}$} & \multicolumn{2}{|c|}{$\begin{array}{l}\text { Kadar gula } \\
\text { darah sedang }\end{array}$} & \multicolumn{2}{|c|}{ Total } & & \\
\hline & $\mathbf{n}$ & $\%$ & $\mathbf{n}$ & $\%$ & $\mathbf{n}$ & $\%$ & & \\
\hline Tidak baik & 41 & 71,9 & 16 & 28,1 & 57 & 100 & & \\
\hline Baik & 10 & 40 & 15 & 60 & 25 & 100 & 0,013 & $3,844(1,433-10,313)$ \\
\hline Total & 51 & 62,2 & 31 & 37,8 & 82 & 100 & & \\
\hline
\end{tabular}

Berdasarkan tabel 4 diatas dari 57 responden dengan jadwal makanan yang tidak baik, yang memiliki kadar gula darah buruk sebanyak 41 responden (71,9\%). Dari 25 responden dengan jadwal makanan yang baik, yang memiliki kadar gula darah buruk sebanyak 10 responden (40\%). Hasil uji statistik chi square, diperoleh $p$ value $=0,013$ artinya $p$ value kecil dari 0,05 maka ada hubungan yang signifikan antara jadwal makanan dengan kadar gula darah di RSUD Petala Bumi Pekanbaru.

Nilai Prevalensi Odds Ratio (POR) $=3,844$ dengan nilai Confidence Interval $95 \%(\mathrm{Cl})=$ 1,433-10,313 artinya responden dengan jadwal makanan yang tidak baik 3,8 kali berpeluang memiliki kadar gula darah buruk daripada responden dengan jadwal makanan yang baik.

Berdasarkan hasil penelitian ada hubungan yang signifikan antara jadwal makanan dengan kadar gula darah di RSUD Petala Bumi Pekanbaru. Nilai Prevalensi Odds Ratio (POR) = 3,844 dengan nilai Confidence Interval $95 \%(\mathrm{Cl})$ $=1,433-10,313$ artinya responden dengan jadwal makanan yang tidak baik 3,8 kali berpeluang memiliki kadar gula darah buruk daripada responden dengan jadwal makanan yang baik.

Pada penelitian Toharin (2015) menunjukkan bahwa ada hubungan antara aturan jadwal makan dengan kadar gula darah pada penderita DM tipe $2(p=0,031) .{ }^{10}$ Selain itu, penelitian Kurniawati (2007) juga menunjukkan adanya hubungan antara aturan jadwal makan dengan kadar gula darah $(p=0,003) .{ }^{5}$ Perlu adanya pengaturan jadwal makan bagi penderita DM tipe 2, karena keterlambatan atau keseringan makan akan mempengaruhi kadar gula darah. ${ }^{14}$ Penelitian oleh Susanti (2018) juga mengungkapkan bahwa ada hubungan antara pola makan dengan kadar gula darah pada penderita DM. ${ }^{15}$

Pada penelitian eksperimen Jakubowicz (2015) untuk melihat apakah jadwal makan dapat mengurangi kadar glukosa darah maka dilakukakan dua hari pengujian makan terpisah, masing-masing selama 14 jam. ${ }^{16}$ Reponden mengkonsumsi makanan besar atau utama pada sarapan pagi jam 08.00, makan siang jam 13.00, dan makan malam jam 19.00. Didapatkan hasil bahwa asupan energi yang sesuai dengan kebutuhan energi responden pada sarapan pagi, siang, dan malam maka glukosa plasma akan mengalami penurunan sebesar $10 \%(p<0,006$, ttest).

Menurut analisis peneliti, jadwal makan responden yang teratur dapat menstabilkan kadar gula darah. Responden dianjurkan agar tetap mempertahankan kestabilan kadar gula darahnya dengan pengaturan pola makan yang tepat sesuai dengan anjuran $3 \mathrm{~J}$ (Jadwal, Jumlah dan Jenis). Pengaturan jadwal makan sangatlah penting bagi penderita DM tipe 2 karena dengan membagi waktu makan menjadi porsi kecil tetapi sering, karbohidrat dicerna dan diserap secara lebih lambat dan stabil. Selain itu, kebutuhan insulin pun menjadi lebih rendah dan sensitivitas insulin menjadi meningkat sehingga metabolisme tubuh dapat berjalan dengan lebih baik. Membagi makanan menjadi beberapa porsi kecil dengan frekuensi lebih sering pada makan besar dan selingan lebih efektif untuk menjaga gula darah terus berada dalam batas normal. Jika semakin jauh jarak antara makan pertama dengan makan kedua atau antara mengudap selingan, maka semakin besar makan yang diminta. Jadi, dapat dikatakan bahwa pada penelitian ini responden lebih mengkonsumsi makanan pada waktu makan besar dibandingkan dengan selingan. Sehingga kemungkinan untuk menerapkan jadwal makan 3 kali makan dan 3 kali selingan lebih sulit karena kebiasaan dan kesibukan responden.

\section{Hubungan Aktivitas Fisik dengan Kadar Gula Darah}

Hubungan aktivitas fisik dengan kadar gula darah dapat dilihat pada tabel berikut ini: 


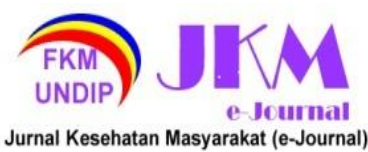

JURNAL KESEHATAN MASYARAKAT (e-Journal)

Volume 9, Nomor 5, September 2021

ISSN: 2715-5617 / e-ISSN: 2356-3346

http://ejournal3.undip.ac.id/index.php/jkm

Tabel 5. Hubungan Antara Aktivitas Fisik dengan Kadar Gula Darah di RSUD Petala Bumi Pekanbaru Tahun 2020

\begin{tabular}{|c|c|c|c|c|c|c|c|c|}
\hline \multirow{3}{*}{$\begin{array}{c}\text { Aktivitas } \\
\text { Fisik }\end{array}$} & \multicolumn{4}{|c|}{ Kadar Gula Darah } & & & \multirow{3}{*}{ P value } & \multirow{3}{*}{$\begin{array}{c}\text { OR } \\
(\text { CI 95\%) }\end{array}$} \\
\hline & \multicolumn{2}{|c|}{$\begin{array}{c}\text { Kadar gula } \\
\text { darah } \\
\text { buruk } \\
\end{array}$} & \multicolumn{2}{|c|}{$\begin{array}{l}\text { Kadar gula } \\
\text { darah sedang }\end{array}$} & \multicolumn{2}{|c|}{ Total } & & \\
\hline & $\mathbf{n}$ & $\%$ & $\mathrm{n}$ & $\%$ & $\mathrm{n}$ & $\%$ & & \\
\hline Tidak baik & 36 & 80 & 9 & 20 & 45 & 100 & & \\
\hline Baik & 15 & 40,5 & 22 & 59,5 & 37 & 100 & 0,001 & $5,867(2,198-15,662)$ \\
\hline Total & 51 & 62,2 & 31 & 37,8 & 82 & 100 & & \\
\hline
\end{tabular}

Berdasarkan tabel 6 diatas dari 61 responden dengan aktivitas fisik yang tidak baik, yang memiliki kadar gula darah buruk sebanyak 36 responden (80\%). Dari 37 responden dengan aktivitas fisik yang baik, yang memiliki kadar gula darah buruk sebanyak 15 responden $(40,5 \%)$. Hasil uji statistik chi square, diperoleh $p$ value $=$ 0,001 artinya $p$ value kecil dari 0,05 maka ada hubungan yang signifikan antara aktivitas fisik dengan kadar gula darah di RSUD Petala Bumi Pekanbaru.

Nilai Prevalensi Odds Ratio (POR) $=5,867$ dengan nilai Confidence Interval 95\% $(\mathrm{Cl})=$ 2,198-15,662 artinya responden dengan aktivitas fisik yang tidak baik 5,1 kali berpeluang memiliki kadar gula darah buruk daripada responden dengan aktivitas fisik yang baik.

Berdasarkan hasil penelitian ada hubungan yang signifikan antara aktivitas fisik dengan kadar gula darah di RSUD Petala Bumi Pekanbaru. Nilai Prevalensi Odds Ratio (POR) $=$ 5,867 dengan nilai Confidence Interval $95 \%(\mathrm{Cl})$ $=2,198-15,662$ artinya responden dengan aktivitas fisik yang tidak baik 5,1 kali berpeluang memiliki kadar gula darah buruk daripada responden dengan aktivitas fisik yang baik.

Hasil penelitian cross-sectional Teh, et.al (2015) di Malaysia dengan sampel penderita DM yang merupakan masyarakat urban dan rural menunjukkan adanya hubungan signifikan antara aktivitas fisik dengan pengontrolan glukosa darah $(p<0,05) \cdot{ }^{9}$ Hal tersebut serupa dengan penelitian Anani, et.al (2012) di Cirebon menunjukkan adanya hubungan antara kebiasaan olahraga atau aktivitas fisik dengan kondisi glukosa darah penderita DM tipe 2 $(p=0,041)$.

Pada penderita DM tipe 2, aktivitas fisik juga berperan utama dalam pengaturan kadar gula darah. ${ }^{6}$ Dalam PERKENI (2011) juga disebutkan bahwa olahraga teratur dapat memperbaiki kendali glukosa darah, mempertahankan atau menurunkan berat badan, serta dapat meningkatkan kadar kolesterol HDL. ${ }^{2}$ Masalah utama pada penderita DM tipe 2 adalah kurangnya respon reseptor terhadap insulin (resistensi insulin). Karena adanya gangguan tersebut, insulin tidak dapat membantu transfer glukosa ke dalam sel. ${ }^{6}$

Aktivitas fisik merupakan suatu irama sirkadian pada manusia. Masing-masing individu memiliki irama yang unik dalam kehidupannya sehari-hari dalam melakukan aktivitasnya, baik untuk bekerja, makan, istirahat, rekreasi dan lain sebagainya. Dalam memenuhi kebutuhan tersebut, maka dibutuhkan koordinasi, keamanan, dan keefisienan agar menghasilkan gerakan yang baik dan dapat memelihara keseimbangan selama beraktivitas tersebut. Kurangnya aktivitas merupakan salah satu faktor yang ikut berperean yang meyebabkan resistensi insulin pada diabetes melitus tipe II. individu yang aktif memiliki insulin dan profil glukosa yang lebih baik dari pada individu yang tidak aktif. Mekanisme aktivitas fisik dalam mencegah atau menghambat perkembangan diabetes melitus tipe II. Aktivitas fisik yang kurang menyebabkan resistensi insulin pada diabetes melitus tipe II. Diabetes Melitus tipe II selain factor genetik, juga bisa dipicu oleh lingkungan yang menyebabkan perubahan gaya hidup tidak sehat, seperti makan berlebihan (berlemak dan kurang serat), kurang aktivitas fisik dan stress. Diabetes Mellitus tipe II sebenarnya dapat dikendalikan atau dicegah terjadinya melalui gaya hidup sehat, seperti makanan sehat dan aktivitas fisik teratur. ${ }^{6}$

Menurut analisis peneliti, bila seseorang dengan pola aktivitas yang ringan dapat mengakibatkan meningkatnya kadar gula darah dalam tubuh. Adanya pergerakan tubuh berupa aktivitas fisik yang teratur dengan intensitas yang cukup, dapat mengendalikan kadar gula darah pasien DM tipe 2. Aktivitas fisik yang baik yang dapat dilakukan oleh penderita DM yaitu jalan cepat, yoga, berseda dan berenang. Aktivitas fisik yang dimaksud dalam penelitian ini adalah aktivitas yang mencakup semua olahraga, semua gerakan tubuh, semua pekerjaan, rekreasi, kegiatan sehari-hari, dan kegiatan pada waktu senggang. Berdasarkan hasil pengukuran aktivitas fisik menggunakan kuesioner, diketahui 


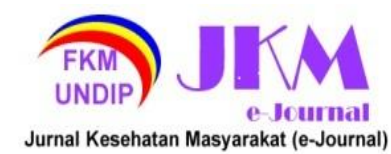

bahwa jenis aktivitas yang umumnya dilakukan responden adalah berjalan kaki yang merupakan jenis ketahanan (endurance) yang dapat membantu jantung, paru-paru, otot, dan sirkulasi darah agar tetap sehat dan bertenaga

\section{KESIMPULAN}

Berdasarkan hasil penelitian dan pembahasan dapat disimpulkan bahwa sebagian besar responden memiliki kadar gula darah buruk sebanyak 51 responden $(62,2 \%)$. Sebagian besar responden memiliki jumlah makanan yang tidak baik sebanyak 61 responden $(74,4 \%)$. Sebagian besar responden memiliki jenis makanan yang tidak baik sebanyak 63 responden $(76,8 \%)$. Sebagian besar responden memiliki jadwal makanan yang tidak baik sebanyak 57 responden $(69,5 \%)$. Sebagian besar responden memiliki aktivitas fisik yang tidak baik sebanyak 45 responden $(54,9 \%)$ sehingga dapat dikatakan bahwa ada hubungan antara jumlah makanan, jenis makanan, jadwal makanan dan aktivitas fisik terhadap status kadar gula darah pada penderita DM Tipe 2 di RSUD Petala Bumi Pekanbaru tahun 2020.

\section{UCAPAN TERIMAKASIH}

Terimakasih peneliti ucapakan kepada seluruh pihak yakni STIKes Hang Tuah Pekanbaru, Rumah Sakit Petala Bumi Pekanbaru yang telah banyak membantu proses mulai dari perizinan, saat melaksanakan penelitian ini hingga penelitian ini selesai tepat waktu..

\section{DAFTAR PUSTAKA}

1. Dorlan, Newman. Kamus Kedokteran Dorland. Jakarta: EGC. 2012.

2. PERKENI. Konsensus Pengendalian dan Pencegahan Diabetes Mellitus Tipe $2 \mathrm{Di}$ Indonesia 2011. Jakarta: PERKENI. 2011.

3. Waspadji, Sarwono. Diabetes Mellitus: Mekanisme Dasar dan Pengelolaannya yang Rasional dalam: Penatalaksanaan Diabetes Mellitus Terpadu. Jakarta: Balai Penerbit FK UI. 2011

4. Verawati, R.R., Hadi, H. \& Aprilia, V. Pola Makan Berhubungan dengan Kadar Gula Darah Pasien Diabetes Mellitus di Instalasi Rawat Inap RSUD Saras Husada Purworejo. Jurnal Gizi dan Dietetik Indonesia. 2014; 2 (2), 74-79.

5. Kurniawati, $D$,. Faktor-Faktor yang Berhubungan dengan Pengontrolan Kadar Glukosa Darah Penderita Diabetes Mellitus Rawat Jalan Rumah Sakit Bhakti Wira Tamtama Semarang. Universitas Negeri
Semarang. 2017.

6. Ilyas, Ermita. Latihan Jasmani bagi Penyandang Diabetes Mellitus dalam: Penatalaksanaan Diabetes Mellitus Terpadu. Jakarta: Balai Penerbit FK UI. 2011.

7. Norris, S.L. et al. Long-term Effectiveness of Lifestyle and Behavioral Weight Loss Interventions in Adults with Type 2 Diabetes: A Meta-analysis. Elsevier. 2014; 117(8), 762-774.

8. Indriyani, P., Supriyatno, H. \& Santoso, A. Pengaruh Latihan Fisik; Senam Aerobik Terhadap Penurunan Kadar Gula Darah Pada Penderita Dm Tipe 2. Media Ners. 2017; 1(2).

9. Teh, C.H. et al. Association of physical activity with blood pressure and blood glucose among Malaysian adults: a population-based study. BMC Public Health. 2015; 15(1205), 1-7

10. Toharin, Syamsi, dkk. Hubungan Modifikasi Gaya Hidup dan Kepatuhan Konsumsi Obat Antidiabetik dengan Kadar Gula Darah pada Penderita Diabetes Melitus Tipe 2 di RS Qim Batang. Unnes Journal of Public Health. 2015; 4(2), 153-161

11. Muliani, Usdeka. Asupan Zat-zat Gizi dan Kadar Gula Darah Penderita DM Tipe 2 di Poliklinik Penyakit Dalam RSUD Dr. H. Abdul Moeloek Provinsi Lampung. Jurnal Gizi Poltekkes Kemenkes Tanjungkarang. 2014; 4(2), 325-332

12. Setyoadi. Influence of Nutrition Education with Calender Method in Diabetic Patients Blood Glucose. Nurseline journal. 2018; 3(2).

13. Almatsier, Sunita. Penuntun Diet. Jakarta: PT Gramedia Pustaka. 2006.

14. Sukardji, Kartini. Penatalaksanaan Gizi pada Diabetes Mellitus dalam: Penatalaksanaan Diabetes Mellitus Terpadu. Jakarta: Balai Penerbit FK UI. 2011.

15. Susanti. Hubungan Pola Makan dengan Kadar Gula Darah Penderita Diabetes Melitus. Jurnal Kesehatan Vokasional. 2018; 3(1).

16. Jakubowicz, D., dkk. Fasting Until Noon Triggers Increased Postprandial Hyperglycemia And Impaired Insulin Response After Lunch And Dinner In Individuals With Type 2 Diabetes: A Randomized Clinical Trial. Journal of Diabetes Cara. 2019; 38(10). 